\title{
The Effect of Work Motivation and Leadership Styles on Employee Performance (Case Study at the Class III Port Administration Unit Office - Serui, Yapen Regency, Papua)
}

\section{Rifai Karim}

Universitas Terbuka, Indonesia

rifaikarim4@gmail.com

\begin{abstract}
The purpose of this study was to analyze work motivation and leadership style on employee performance. This research is a quantitative study using the method of causality analysis. The sample of this study was 53 employees of the Class III Serui Port Administration Unit (KUPP). The research instrument was a questionnaire with a 5-point Likert scale. Data were analyzed by multiple linear regression test. The results of this study indicate that 1) work motivation has a significant effect on employee performance at the Class III Serui Papua Port Administration Unit Office. The higher the work motivation possessed by employees, the higher the resulting performance. 2) Leadership style has a significant effect on the performance of employees at the Serui Papua Class III Port Administration Unit Office.
\end{abstract}

\section{Keywords}

work motivation; leadership style; employee performance; KUPP

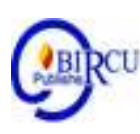

\section{Introduction}

A seaport is one of the strategic infrastructures that support economic activities in various countries (Dwarakish \& Salim, 2015; Munim \& Schramm, 2018). The seaport makes a real contribution to national development and economic growth in Indonesia, a maritime country (Jansen et al., 2018). Proper and professional management is the main requirement to improve the service of a port (Manuel et al., 2004; Abdiyanto \& Warokka, 2015).

The Serui Port Administration Unit (KUPP) office, Papua Yapen Islands Regency, is a strategic Class III port located in the southern part of Yapen Island. The performance of KUPP Serui, can be seen from the Annual Report on Arrival and Departure of Ships (LK3) regarding the number of passengers, goods, or containers being unloaded and loaded at Serui Port. Figure 1 shows that the performance of KUPP Serui has not been optimal, as seen from the number of passengers, goods, and containers unloaded and loaded at Serui Port. The number of passengers tends to fluctuate from 2014 to 2015. It has decreased significantly in 2016 and 2017. In addition, the number of containers loaded and unloaded also decreased in 2017.

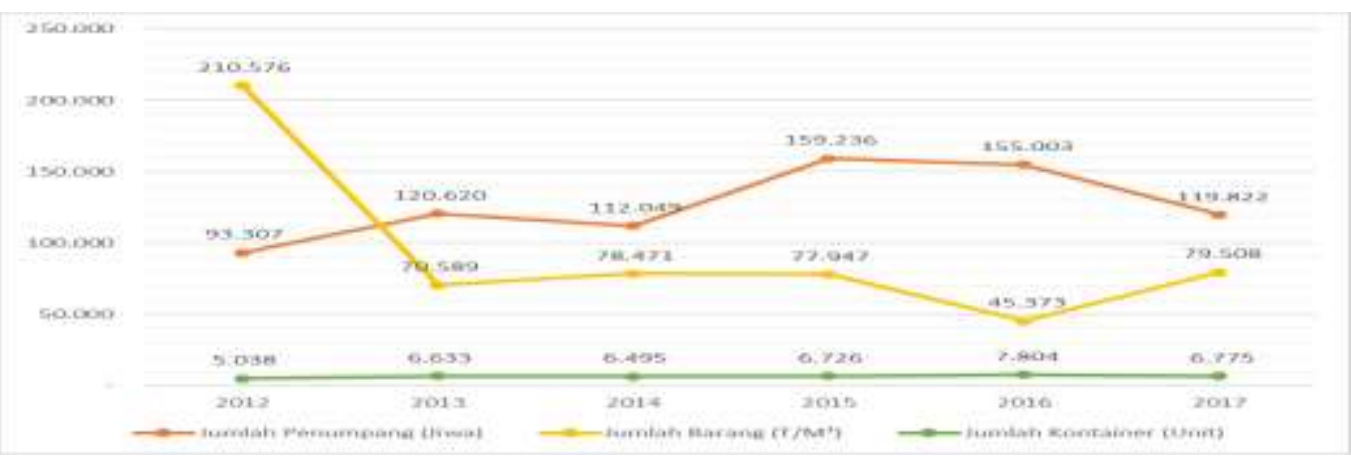

Figure 1. Operational Data for Serui KUPP 2012-2017

Source: Annual Report on Arrival and Departure of the KUPP Serui Ship 
The not yet optimal performance of KUPP Serui can also be seen from the many complaints in public dissatisfaction directed at KUPP Serui in terms of service. So many criticisms and complaints, both directly and indirectly, were sent by the community to KUPP Serui. Various complaints from users of these services reflect sub-optimal employee performance (Hilman \& Warokka, 2011).

Several previous studies have examined the factors that influence employee performance in various KUPPs in Indonesia (Febrilia et al., 2011; Martapina \& Warokka, 2018). Muchzen et al. (2019) examined the performance of KUPP employees in Barru Regency, South Sulawesi. They concluded that the factors affecting the performance of KUPP employees were motivation, compensation, and work discipline. Next, Sjarief (2020) found that the low workability and work motivation led to the low performance of employees in KUPP Surabaya. Sugito and Ghoniyah (2017) examined the performance of employees at KUPP Jepara. Many of KUPP Jepara's employees were less disciplined and stressed due to workloads that were too heavy, under pressure from superiors, and lack of assertiveness of managers. In addition, information technology quality factors and commitment also significantly affect employee performance in KUPP Jepara (Rizan et al., 2020). Ekaningsih et al. (2020) found that organizational culture and work environment significantly affected employee performance at KUPP Tarakan, North Kalimantan. Pradana et al. (2016) concluded that work motivation and interpersonal competence positively and significantly affect employee performance in KUPP Buleleng.

Referring to previous studies that examined the performance of employees at KUPP, the researchers distributed initial questionnaires to 20 respondents who were employees of KUPP Serui. Respondents were asked to choose one or more factors influencing their performance in KUPP Serui. The results of the initial questionnaire analysis described in Table 1 show that work motivation and leadership style are the factors most frequently chosen by respondents as factors that affect the performance of observed employees.

Table 1. Initial Questionnaire Results

\begin{tabular}{clcc} 
No. & \multicolumn{1}{c}{ Factors } & $\begin{array}{c}\text { Number of } \\
\text { Respondents' } \\
\text { Responses }\end{array}$ & $\begin{array}{c}\text { Percentage } \\
(\%)\end{array}$ \\
\hline 1. & Work motivation & 16 & $80 \%$ \\
\hline 2. & Leadership Style & 14 & $70 \%$ \\
\hline 3. & Compensation & 6 & $30 \%$ \\
\hline 4. & Work Discipline & 6 & $30 \%$ \\
\hline 5. & Competence & 7 & $35 \%$ \\
\hline 6. & Organizational culture & 5 & $25 \%$ \\
\hline 7. & Work environment & 5 & $25 \%$ \\
\hline 8. & Organizational Commitment & 5 & $25 \%$ \\
\hline 9. & Information Technology & 4 & $20 \%$ \\
\hline
\end{tabular}

Various studies have shown a positive correlation between motivation and performance (Khan, 2012; Sandhu et al., 2017; Subari \& Riady, 2015; Wright, 2007). In other words, the motivation variable determines the good and bad performance of an employee (Cherian \& Jacob, 2013; Tammubua et al., 2015). The higher the employee's motivation, the better the performance. High motivation encourages employees to carry out their duties with enthusiasm (Lee \& Hidayat, 2018). However, the Serui Class III KUPP's employees still have low work motivation, where the attendance rate of employees is decreasing day by day as 
indicated by the high number of absences from the previous 10 percent, in 2014 it reached 20 percent.

Meanwhile, from 2012 to early 2013, employee morale decreased as indicated by delays in office hours, lack of response to leadership policies, causing ineffectiveness in implementing work. It reflected the effect of leadership style on decreasing performance (Warokka, 2010). Leadership style plays a vital role in human resource management (Liu et al., 2003; Warokka et al., 2012). A leader must have skills according to their duties and responsibilities to successfully lead an organization (Székely \& Knirsch, 2005). According to Shafie et al. (2013), a leader takes the necessary steps and establishes a good relationship with its members to optimize performance within the organization. Many studies have found a significant positive relationship between leadership style and employee performance (Elqadri, 2015; Risambessy et al., 2012; Fakhri et al., 2020). This study examines the influence of work motivation and leadership style on employee performance of Serui seaport (KUPP Serui), which was relatively understudied in the context of local organization governance.

\section{Review of Literatures}

\subsection{Performance}

Performance determines the achievement of goals (Cianci et al., 2010). The optimal achievement of goals reflects the excellent performance of the individual or group, and vice versa (Midgley et al., 2001). According to Badrianto and Ekhsan (2019), high employee performance is expected by the company. The more employees who have high performance, the company's overall productivity will increase so that the company will be able to survive in global competition (Yahya et al., 2012).

Performance is something that every employee must own, where employee performance is critical in a company's productivity (Ratnawati et al., 2020). However, it is made difficult by accumulating stressful challenges in the workplace, excessive bureaucracy, and low levels of motivation and satisfaction that exacerbate stress and poor morale, culminating in poor performance (Jacobsen \& Andersen, 2015). Other empirical evidence proves that various factors influence poor performance. Some of these factors include work motivation and leadership style (Hidayah \& Nazaruddin, 2017).

\subsection{Work Motivation}

Morrison (1993) defines motivation as an individual's tendency to participate in activities that lead to a goal. If the behavior leads to an object or target, good motivation will trigger high targets and achieve work effectiveness. Motivation has an essential role because employees who work with high motivation will be more enthusiastic and effective (Mangkunegara dan Octorend, 2015).

With motivation, human resources can fully perform to help the company increase productivity, reduce operating costs, and increase overall efficiency (Shahzadi et al., 2014). Employee work motivation is fundamental because it is expected that each employee will work harder and enthusiastically to achieve high performance in the future (Chen et al., 2012).

Many previous studies have found a significant positive relationship between work motivation and employee performance (Dapu, 2015; Mohamud et al., 2017; Shahzadi et al., 2014; Twalib dan Kariuki, 2020). Therefore, referring to the previous empirical findings, the first hypothesis is:

H1: Work motivation has a significant effect on the performance of employees. 


\subsection{Leadership Style}

Leadership is one of the determining factors for the success of an organization to achieve its goals (Salahuddin, 2010). How well employees perform depends on how well they are managed by their leaders (Basri et al., 2017). According to Davis and Newstrom (1995), leadership style is a way and approach to provide direction, implement plans, and keep someone motivated. This argument includes the manager's overall pattern of explicit and implicit behavior from the employee's perspective. Luthans (2006) argues that the leadership style is a formula that is in harmony with cultural factors made by the leader to influence the behavior of his followers.

Several studies have seen a significant positive relationship between leadership style and employee performance (Basri et al., 2017; Lumbasi et al., 2016; Syafii et al., 2015). According to Lumbasi et al. (2016), high employee performance is achieved when the leader engages employee decision-making through constant consultation. Therefore, referring to previous empirical findings, the second hypothesis proposed is:

H2: Leadership style has a significant effect on the performance of employees.

The two proposed hypotheses are summarized in the following research model (Figure 1).

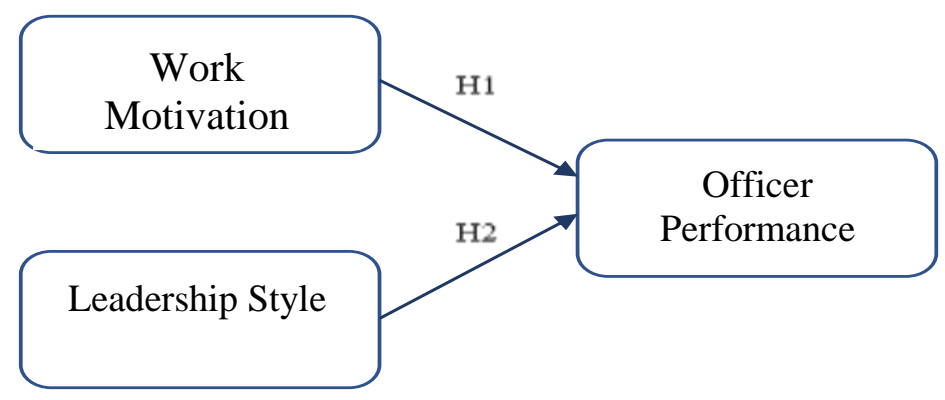

Figure 1. Research Model

\section{Research Methods}

This research is a quantitative study using the method of causality analysis. Causality research is research that examines the relationship between causal variables. One dependent variable in this study, namely employee performance, and two independent variables, namely, work motivation and leadership style. Employees at KUPP Serui, are the population and the sample in this study. The number of observed employees is only 53 employees; therefore, this study uses the saturated sample method or census in determining the research sample. This study used an instrument in the form of a questionnaire with a five-point Likert scale - analysis of research data using the help of the SPSS statistical program. The analytical method used is descriptive analysis, validity and reliability tests, classical assumption tests. 


\section{Discussion}

The total number of observed employees was 53 people with different sexes, education, and employment status. Table 2 describes the respondent's condition in this study as shown in the following table:

Table 2. Description of Respondent Characteristics

\begin{tabular}{cccc}
\hline \multirow{2}{*}{ Category } & Alternative Answers & $\begin{array}{c}\text { Number of } \\
\text { Respondents }\end{array}$ & $\begin{array}{c}\text { Percent } \\
\mathbf{( \% )}\end{array}$ \\
\hline \multirow{2}{*}{ Gender } & Man & 41 & $77.4 \%$ \\
\cline { 2 - 4 } & Women & 12 & $22.6 \%$ \\
\hline \multirow{2}{*}{$\begin{array}{c}\text { Last Education } \\
\text { Level }\end{array}$} & Junior High School & 21 & $39.6 \%$ \\
\cline { 2 - 4 } & High school & 14 & $26.4 \%$ \\
\cline { 2 - 4 } & $\mathrm{D} 3$ & 6 & $11.3 \%$ \\
\cline { 2 - 4 } Employee Status & $\mathrm{S} 1$ & 12 & $22.6 \%$ \\
\cline { 2 - 4 } & Permanent employee & 17 & $32.1 \%$ \\
\cline { 2 - 4 } & Honorary Employee & 36 & $67.9 \%$ \\
\hline
\end{tabular}

Table 2 shows that most of the observed employees are dominated by men (77.4\%). With so many male employees, it is hoped that they can do a good job, especially work in challenging fields to produce a good performance. In addition, the highest level of education for employees is junior high school (39.6\%), and the highest employee status is honorary $(67.9 \%)$.

Furthermore, to describe the conditions and characteristics of the respondents' answers, a descriptive analysis was carried out. Researchers then use the analysis results to determine the tendency of respondents' answers through each of the variables studied. Respondents' answers are categorized by an interval scale calculated from the highest score minus the lowest score divided by five so that the interval is 0.80 . With an interval of 0.80 , the categorization system is as follows: 1.00-1.80 (very low); 1.81-2.60 (low); 2.61-3.40 (sufficient); 3.41-4.20 (high); and 4.21-5.00 (very high).

Table 3. Distribution of Respondents' Opinions

\begin{tabular}{|c|c|c|c|c|c|c|c|c|c|}
\hline \multirow{2}{*}{\multicolumn{2}{|c|}{ Items }} & \multicolumn{5}{|c|}{ Alternative Opinions } & \multirow[t]{3}{*}{ Amount } & \multirow[t]{3}{*}{ Average } & \multirow[t]{3}{*}{ Category } \\
\hline & & STS & TS & CS & $\mathbf{S}$ & SS & & & \\
\hline & & 1 & 2 & 3 & 4 & 5 & & & \\
\hline $\mathrm{X} 1.1$ & $\begin{array}{l}\text { Enough to fulfill } \\
\text { the needs of a } \\
\text { decent daily life } \\
\text { from work }\end{array}$ & 0 & 6 & 32 & 15 & 0 & 53 & 3.17 & Sufficient \\
\hline $\mathrm{X} 1.2$ & $\begin{array}{l}\text { The existence of } \\
\text { health insurance } \\
\text { in dealing with } \\
\text { the risk of } \\
\text { accidents at work }\end{array}$ & 0 & 1 & 26 & 23 & 3 & 53 & 3.53 & High \\
\hline $\mathrm{X} 1.3$ & $\begin{array}{l}\text { The existence of } \\
\text { old age insurance } \\
\text { for employees } \\
\text { (pension } \\
\text { provision) }\end{array}$ & 0 & 4 & 28 & 20 & 1 & 53 & 3.34 & Sufficient \\
\hline
\end{tabular}




\begin{tabular}{|c|c|c|c|c|c|c|c|c|c|}
\hline $\mathrm{X} 1.4$ & $\begin{array}{l}\text { There is a friendly } \\
\text { relationship / } \\
\text { good } \\
\text { communication } \\
\text { between you and } \\
\text { your boss and } \\
\text { fellow employees }\end{array}$ & 0 & 0 & 30 & 23 & 0 & 53 & 3.43 & High \\
\hline $\mathrm{X} 1.5$ & $\begin{array}{l}\text { Willingness of } \\
\text { coworkers to help } \\
\text { when there are } \\
\text { difficulties }\end{array}$ & 2 & 5 & 24 & 21 & 1 & 53 & 3.26 & Sufficient \\
\hline $\mathrm{X} 1.6$ & $\begin{array}{l}\text { There is an } \\
\text { attitude of praise } \\
\text { from superiors } \\
\text { when employees } \\
\text { work well }\end{array}$ & 0 & 6 & 32 & 15 & 0 & 53 & 3.17 & Sufficient \\
\hline $\mathrm{X} 1.7$ & $\begin{array}{l}\text { The provision of } \\
\text { incentives for } \\
\text { employees who } \\
\text { excel. }\end{array}$ & 0 & 5 & 12 & 33 & 3 & 53 & 3.64 & High \\
\hline X1.8 & $\begin{array}{l}\text { Companies } \\
\text { provide } \\
\text { opportunities for } \\
\text { their own } \\
\text { creativity in } \\
\text { carrying out work }\end{array}$ & 0 & 2 & 18 & 24 & 9 & 53 & 3.75 & High \\
\hline $\mathrm{X} 1.9$ & $\begin{array}{l}\text { The company } \\
\text { gave me the } \\
\text { opportunity to } \\
\text { develop myself } \\
\text { through education } \\
\text { and training }\end{array}$ & 0 & 0 & 20 & 26 & 7 & 53 & 3.75 & High \\
\hline \multicolumn{8}{|c|}{ Average } & 3.45 & High \\
\hline $\mathrm{X} 2.1$ & $\begin{array}{l}\text { My boss instructs } n \\
\text { what to do }\end{array}$ & on & 08 & 35 & 10 & 0 & 53 & 3.04 & Sufficient \\
\hline $\mathrm{X} 2.2$ & $\begin{array}{l}\text { My leader invites g } \\
\text { members to jointly } \\
\text { goals and objective } \\
\text { the activity }\end{array}$ & & 03 & 27 & 22 & 1 & 53 & 3.40 & Sufficient \\
\hline $\mathrm{X} 2.3$ & $\begin{array}{l}\text { My leader provides } \\
\text { opportunity for } \\
\text { employees to discu } \\
\text { problems with the } 1 \\
\text { (exchange ideas) }\end{array}$ & he & 06 & 24 & 23 & 0 & 53 & 3.32 & Sufficient \\
\hline $\mathrm{X} 2.4$ & $\begin{array}{l}\text { There is assistance } \\
\text { the leader in a task }\end{array}$ & & 04 & 31 & 17 & 1 & 53 & 3.28 & Sufficient \\
\hline $\mathrm{X} 2.5$ & $\begin{array}{l}\text { There are demands } \\
\text { superiors in the } \\
\text { preparation of a wo } \\
\text { plan }\end{array}$ & rom & 213 & 32 & 6 & 0 & 53 & 2.79 & Sufficient \\
\hline $\mathrm{X} 2.6$ & $\begin{array}{l}\text { The role of superio } \\
\text { solving problems }\end{array}$ & & 08 & 29 & 16 & 0 & 53 & 3.15 & Sufficient \\
\hline X2.7 & Supervision of supe & riors & 07 & 34 & 12 & 0 & 53 & 3.09 & Sufficient \\
\hline
\end{tabular}




\begin{tabular}{|c|c|c|c|c|c|c|c|c|}
\hline & in carrying out duties & & & & & & & \\
\hline $\mathrm{X} 2.8$ & $\begin{array}{l}\text { Requests for reports on } \\
\text { task implementation by } \\
\text { superiors }\end{array}$ & 06 & 24 & 20 & 3 & 53 & 3.38 & Sufficient \\
\hline $\mathrm{X} 2.9$ & $\begin{array}{l}\text { Exemplary superiors to } \\
\text { be honest }\end{array}$ & 03 & 29 & 20 & 1 & 53 & 3.36 & Sufficient \\
\hline \multirow[t]{2}{*}{$\mathrm{X} 2.10$} & $\begin{array}{l}\text { Bosses set an example } \\
\text { (arrive on time) }\end{array}$ & 05 & 26 & 21 & 1 & 53 & 3.34 & Sufficient \\
\hline & Average & & & & & & 3.22 & Enough \\
\hline Y.1 & $\begin{array}{l}\text { The quality of my work } \\
\text { is up to the standards set }\end{array}$ & 02 & 28 & 21 & 2 & 53 & 3.43 & High \\
\hline Y.2 & $\begin{array}{l}\text { The quantity of my } \\
\text { work is in accordance } \\
\text { with the established } \\
\text { standards. }\end{array}$ & 02 & 22 & 24 & 5 & 53 & 3.60 & High \\
\hline Y.3 & $\begin{array}{l}\text { I always understand } \\
\text { very well the purpose, } \\
\text { scope and objectives of } \\
\text { the work being done }\end{array}$ & 08 & 32 & 13 & 0 & 53 & 3.09 & Sufficient \\
\hline Y.4 & $\begin{array}{l}\text { I am involved in solving } \\
\text { company problems if } \\
\text { there are problems }\end{array}$ & 05 & 27 & 18 & 3 & 53 & 3.36 & Sufficient \\
\hline Y.5 & $\begin{array}{l}\text { Ideas or ideas that I } \\
\text { propose are always } \\
\text { accepted and } \\
\text { accommodated as input } \\
\text { that is considered }\end{array}$ & 25 & 35 & 11 & 0 & 53 & 3.04 & Sufficient \\
\hline Y.6 & $\begin{array}{l}\text { I dare to take risks in the } \\
\text { face of a challenging job }\end{array}$ & 06 & 32 & 15 & 0 & 53 & 3.17 & Sufficient \\
\hline Y.7 & $\begin{array}{l}\text { Good teamwork can } \\
\text { make it easier for me to } \\
\text { solve problems }\end{array}$ & 04 & 25 & 21 & 3 & 53 & 3.43 & High \\
\hline Y.8 & $\begin{array}{l}\text { Good communication } \\
\text { relationships can } \\
\text { improve performance }\end{array}$ & 04 & 31 & 15 & 3 & 53 & 3.32 & Sufficient \\
\hline Y.9 & $\begin{array}{l}\text { Needing other people at } \\
\text { work will help me get } \\
\text { the job done }\end{array}$ & 10 & 23 & 24 & 5 & 53 & 3.60 & High \\
\hline Y.10 & $\begin{array}{l}\text { Carrying out an activity } \\
\text { is preceded by thinking } \\
\text { about positive things. }\end{array}$ & 017 & 28 & 6 & 2 & 53 & 2.87 & Sufficient \\
\hline Y.11 & $\begin{array}{l}\text { I always do work } \\
\text { independently and am } \\
\text { open to other people's } \\
\text { opinions. }\end{array}$ & 07 & 32 & 13 & 1 & 53 & 3.15 & Sufficient \\
\hline Y.12 & $\begin{array}{l}\text { I like to have many } \\
\text { friends and quickly } \\
\text { adapt to the environment } \\
\text { in doing work. }\end{array}$ & 01 & 29 & 22 & 1 & 53 & 3.43 & High \\
\hline Y.13 & $\begin{array}{l}\text { I am skilled and have } \\
\text { good intelligence to } \\
\text { complete the given job. }\end{array}$ & 010 & 21 & 21 & 1 & 53 & 3.25 & Sufficient \\
\hline
\end{tabular}


Note:STS = Strongly Disagree; TS = Disagree; $\mathrm{N}=$ Neutral; $\mathrm{S}=$ Agree; $\mathrm{SS}=$ Strongly Agree, $\mathrm{X} 1=$ Work Motivation; X2 = Leadership; $\mathrm{Y}=$ Employee Performance.

Based on the distribution of respondents' answers, the work motivation variable has an average value of 3.45, which is categorized as a high level, and the leadership variable has an average value of 3.22, categorized as a sufficient level. Meanwhile, the employee performance variable has an average value of 3.29 belonged to the sufficient level. This finding shows that the observed employees have good work motivation, and leadership implementation is also quite good.

Table 4. Validity and Reliability Test Results

\begin{tabular}{lcc}
\hline Item & R Count & Cronbach's Alpha \\
\hline X1.1 & 0.611 & \\
X1.2 & 0.466 & \\
X1.3 & 0.598 & \\
X1.4 & 0.518 & \\
X1.5 & 0.679 & \\
X1.6 & 0.582 & \\
X1.7 & 0.607 & \\
X1.8 & 0.361 & \\
X1.9 & 0.537 & \\
\hline X2.1 & 0.637 & \\
X2.2 & 0.509 & \\
X2.3 & 0.561 & \\
X2.4 & 0.371 & \\
X2.5 & 0.697 & \\
X2.6 & 0.614 & \\
X2.7 & 0.622 & \\
X2.8 & 0.581 & \\
X2.9 & 0.354 & \\
X2.10 & 0.524 & \\
\hline Y.1 & 0.482 & \\
Y.2 & 0.394 & \\
Y.3 & 0.624 & \\
Y.4 & 0.513 & \\
Y.5 & 0.611 & \\
Y.6 & 0.648 & \\
Y.7 & 0.570 & \\
Y.8 & 0.571 & \\
Y.9 & 0.459 & \\
Y.10 & 0.450 & \\
Y.11 & 0.509 & \\
Y.12 & 0.318 & \\
\hline Y.13 & 0.560 & \\
\hline
\end{tabular}

Validity and reliability tests were carried out to measure the accuracy of the research instrument through the statement items/questions raised in the study. The validity test is intended to determine the degree of accuracy of the instruments used to measure the empirical indicators of the research variables. In contrast, the reliability test is intended to 
measure the level of reliability of the data obtained. Validity is tested using the productmoment formula to obtain $r$ statistics and compare it with the $r$ table value of 0.271 . A reliability test is done by looking at the value of Cronbach's alpha. The validity and reliability tests in Table 4 show that all questions in the motivation, leadership and performance variables have a statistical value of $r>r$ table $(0.271)$, and all variables have a Cronbach's alpha value> 0.6. Therefore it can be concluded that all variables are valid and reliable.

Table 5. Classical Assumption Test Results

\begin{tabular}{ccccccc}
\hline \multicolumn{2}{c}{ Normality test } & & \multicolumn{2}{c}{ Multicollinearity Test } & \multicolumn{2}{c}{$\begin{array}{c}\text { Hetercedasticity } \\
\text { Test }\end{array}$} \\
\hline $\begin{array}{c}\text { Kolmogorov } \\
\text { Smirnov }\end{array}$ & $\begin{array}{c}\text { Asymp. } \\
\text { Sig }\end{array}$ & Variable & Tolerance & VIF & Sig value & $\begin{array}{c}\text { Sig } \\
\text { limit }\end{array}$ \\
\hline \multirow{2}{*}{1,110} & 0.158 & $\mathrm{X} 1$ & 0.493 & 2,027 & 0.095 & 0.05 \\
\cline { 4 - 7 } & & $\mathrm{X} 2$ & 0.493 & 2,027 & 0.113 & 0.05 \\
\hline
\end{tabular}

Before testing the hypothesis, this study conducted normality, heteroscedasticity, and multicollinearity tests. The normality test is carried out to see the normality of the data in a regression model that tests the relationship between the dependent and independent variables. The normality test was carried out using Kolmogorov Smirnov. The results of the normality test in Table 5 indicate that the value is obtained in Asymp. Sig of 0.158, more significant than 0.05 , so the data is normally distributed.

Furthermore, the heteroscedasticity test aims to test whether there is an inequality of variants from the residuals of one observation to another in the regression model. The results show that all beta parameter coefficients of the regression equation are not statistically significant, so there is no heteroscedasticity problem. Then the multicollinearity test is also carried out by looking at the tolerance value and variance inflation factor (VIF). These two measures indicate which the other independent variables explain the independent variable. The test results in Table 5 show that the two variables have a tolerance value above 0.10 and a VIF value below 10, so the two independent variables do not experience multicollinearity symptoms.

Table 6. Results of Multiple Regression Analysis and Hypothesis Testing

\begin{tabular}{|c|c|c|c|c|c|c|}
\hline \multirow{2}{*}{\multicolumn{2}{|c|}{ Model }} & \multicolumn{2}{|c|}{$\begin{array}{c}\text { Unstandardized } \\
\text { Coefficients }\end{array}$} & \multirow{2}{*}{$\begin{array}{c}\begin{array}{c}\text { Standardized } \\
\text { Coefficients }\end{array} \\
\text { Beta }\end{array}$} & \multirow[b]{2}{*}{$\mathrm{t}$} & \multirow[b]{2}{*}{ Sig. } \\
\hline & & $\mathrm{B}$ & Std. Error & & & \\
\hline \multirow[t]{4}{*}{1} & (Constant) & 8,935 & 4,325 & & 2,066 &, 044 \\
\hline & Work motivation & 0.416 & 0.186 & 0.299 & 2,236 & 0.030 \\
\hline & Leadership Style & 0.650 & 0.172 & 0.504 & 3,771 & 0,000 \\
\hline & Adjusted R Square & 0.541 & & & & \\
\hline
\end{tabular}

After the data is declared valid, reliable, and fulfills the classical assumption test, this study conducted the multiple linear regression test. Based on Table 6, if included in the general equation for multiple linear regression is:

$$
\mathrm{Y}=8.935+0.416 \mathrm{X} 1+0.650 \mathrm{X} 2+\varepsilon
$$


This finding can be interpreted as follows:

1. The constant is 8.935, meaning that if the work motivation and leadership style variables are considered constant (0) or there is no change, then the employee performance variable is 8.935 .

2. The regression coefficient of work motivation is 0.416 , meaning that if the variable of leadership style is considered constant (0) or there is no change. Each increase in work motivation by 1 unit will affect increasing employee performance by 0.416 .

3. The leadership style regression coefficient is 0.650 , meaning that if the work motivation variable is considered constant $(0)$ or there is no change. Every 1 unit increase in leadership style will affect increasing employee performance by 0.650 .

4. Score Standardized Coefficients Beta the leadership style variable, has the highest value of 0.504 compared to the value of other independent variables. It shows that the leadership style variable has the most significant contribution to employee performance.

Furthermore, the T-test was carried out to determine the effect of work motivation and leadership style variables partially on employee performance variables. The $t$ value of the work motivation variable is 2,236 smaller than the t table 1.97 with a significance level of 0.030 , meaning that partially the work motivation variable has a significant effect on the employee performance variable. So the first hypothesis, which states that work motivation has a significant effect on employees' performance, is accepted.

The results of this study support the results of previous studies, which state that work motivation has a positive and significant effect on employee performance (Dapu, 2015; Mohamud et al., 2017; Shahzadi et al., 2014; Twalib and Kariuki, 2020). This finding means that motivating the observed employees tends to improve employee performance, which can help the company achieve its goals. The results of the analysis of respondents 'answers show that the employees' self-actualization needs in KUPP Serui have been well fulfilled compared to other needs to improve performance. Employees at KUPP Serui have been creative and carry out self-development through education and training. Employees are allowed to realize and develop their potential (Maslow, 1954), and therefore he is increasingly motivated and influences his better performance. KUPP Serui employees feel that physiological needs are lacking, so that it must be paid more attention because it is the most basic need.

Furthermore, in the leadership style variable, the $\mathrm{t}$-value is 3.771 , more significant than t-table 1.97 with a significance level of 0.000 , meaning that the leadership style variable has a significant positive effect on employee performance variables. This finding means that the better the leadership style a leader has, the higher the employee's performance. So the second hypothesis, which states that leadership style has a significant effect on observed employee performance, is accepted.

These results are in line with the research Elqadri (2015), Risambessy et al. (2012), Fakhri et al. (2020), and Fatimah et al. (2020), which states that there is a positive and significant influence of leadership style on employee performance. This finding means that the leadership style given can improve employee performance. Leaders in KUPP Serui, can be good role models for employees. Leaders set an example by being honest and arriving on time. In addition, the leader has also supervised employees when carrying out tasks and asked employees to make reports on the implementation of duties.

The results of this study also support transformational leadership theory. Transformational leadership is a style that inspires followers to prioritize common interests and has a profound impact on their followers (Robbins, 2007). The leader in KUPP Serui provides a good role model for his subordinates, giving a more personal impact on his followers. In addition, leaders also focus on developing the skills of their followers and helping to solve problems. 
When referring to the House theory (1971), the leader of KUPP Serui performs a participatory leadership style. The leader is open to input and suggestions from members of the organization. Leaders in KUPP Serui are also good at exchanging ideas with employees and providing clear assignments. With participatory leadership, employees feel empowered to produce higher performance because they feel their work and voice are valued.

Furthermore, the results of the R-square test (coefficient of determination) were carried out to measure the ability of the work motivation variable model (X1) and leadership style (X2) in explaining the variation in employee performance variables (Y). Based on the test results, the Adjusted R Square value is 0.541 , which can be interpreted that the ability of the variable model of work motivation and leadership style can affect the performance variables, Yapen Islands Regency by $54.1 \%$. The remaining $45.9 \%$ is influenced by other variables that were not examined in this study.

\section{Conclusion}

Based on theoretical descriptions and analysis, several conclusions can be drawn: (1) work motivation has a significant positive effect on employee performance. The higher the employees' work motivation, the higher their performance; (2) leadership style significantly positively affects employee performance. The better the leader's leadership style applies to his employees, the better the employee's performance.

In this study, there are several limitations of the study, first, this study only used a small research sample and a small research scope, so that the results of the study could not be generalized to a broader population. Second, this study only focuses on two factors that influence performance: work motivation and leadership style. There are still many factors that might cause the high and low performance of observed employees. Third, this study only uses a questionnaire research instrument based only on the respondents' perceptions.

Referring to the conclusions and limitations of the study, the researcher suggests that the leaders in KUPP Serui, should conduct a review related to the primary/physiological needs of the employees, whether it is sufficient with the amount of salary given. In addition, it is suggested that the leadership should provide a more substantial influence on employees. The observed employees should foster their motivation at work, create a sense of empathy and sympathy with colleagues, and establish good relationships with leaders so that a family attitude can encourage employee performance. Furthermore, future research is expected to explore other factors that can improve employee performance, such as interpersonal communication, work environment, and other variables. The next researcher must add a mediating variable and a moderating variable to develop and explain the factors that affect employee performance in more detail. In addition, future researchers are expected to rely on questionnaires as a research instrument and be supported by interview results.

\section{References}

Abdiyanto \& Warokka, A. (2015). Priority-Driven Budgeting Policy and Regional Inequality: Does Economic Structure Transformation Really Perform as Intervening Variable? Journal of Economics Studies and Research, Vol. 2015 (2015), Article ID 216353, c118. DOI: $10.5171 / 2015.216353$

Arsani et al. (2020). Differences in Motivational Orientation in Physical Education in terms of Gender Differences. Budapest International Research and Critics in Linguistics and Education (BirLE) Journal Vol 3 (3): 1428-1434. 
Asriani, A., Lorensa, D., Saputri, F., \& Hidayati, T. (2020). The Effect of Compensation and Motivation To Employee Performance. International Journal of Economics, Business and Accounting Research (IJEBAR), 4(01), 166-172.

Badrianto, Y., \& Ekhsan, M. (2019). The Effect of Work Environment and Motivation on Employee Performance of Pt. Hasta Multi Sejahtera Cikarang. Journal of Reseacrh in Business, Economics, and Education, 1(1), 64-70.

Basri, H. H., Rashid, I. M. A., Abashah, A. B., \& Samah, I. H. A. (2017). The Roles Of Transformational Leadership Style For Maintaining Employee In Team Performance: Empirical Study In Malaysia' Pharmacy Industry. International Journal of Information, Business and Management, 9(2), 37-44.

Chen, Y.-Y., Park, J., \& Park, A. (2012). Existence, relatedness, or growth? Examining turnover intention of public child welfare caseworkers from a human needs approach. Children and Youth Services Review, 34(10), 2088-2093. https://doi.org/10.1016/j.childyouth.2012.07.002

Cherian, J., \& Jacob, J. (2013). Impact of self efficacy on motivation and performance of employees. International Journal of Business and Management, 8(14), 80-88. https://doi.org/10.5539/ijbm.v8n14p80

Cianci, A. M., Schaubroeck, J. M., \& McGill, G. A. (2010). Achievement goals, feedback, and task performance. Human Performance, 23(2), 131-154. https://doi.org/10.1080/08959281003621687

Dapu, V. A. W. (2015). The Influence Of Work Discipline, Leadership, And Motivation On Employee Performance At PT Trakindo Utama Manado. Jurnal EMBA, 3(3), 352-361.

Davis, K., \& Newstrom, J. W. (1995). Perilaku dalam Organisasi. Jakarta : Erlangga.

Dwarakish, G. S., \& Salim, A. M. (2015). Review on the Role of Ports in the Development of a Nation. Aquatic Procedia, 4, 295-301. https://doi.org/10.1016/j.aqpro.2015.02.040

Ekaningsih, A. S., Sonu, K., Kristianto, T., \& Manalu, M. (2020). The Effect of Organizational Culture to Employee Performance Through the Work Environment in Harbormastership and Authority of Port Class III Tarakan. Proceedings of the International Conference on Industrial Engineering and Operations Management Dubai, UAE, 2046-2056.

Elqadri, Z. M. (2015). Effect of Leadership Style, Motivation, and Giving Incentives on the Performance of Employees--PT. Kurnia Wijaya Various Industries. International Education Studies, 8(10), 183-192. https://doi.org/10.5539/ies.v8n10p183

Fakhri, M., Pradana, M., Syarifuddin, S., \& Suhendra, Y. (2020). Leadership Style and its Impact on Employee Performance at Indonesian National Electricity Company. The Open Psychology Journal, 13(1), 321-325. https://doi.org/10.2174/187435010201301 0321

Fatimah, Omar, H., Muhammad, I., Choiriyah, \& Yusmaniar. (2020). Factors Affecting the Performance of State Civil Apparatus: A study in the religious office of Palembang City, Indonesia. International Journal of Innovation, Creativity, and Change, 12(3), 344-355.

Febrilia, I., Warokka, A., \& Abdullah, H. H. (2011). University students' emotional state and academic performance: New insights of managing complex cognitive. Journal of eLearning and Higher Education, Vol. 2011 (2011), Article ID 879553, 1-15. DOI: $10.5171 / 2011.879553$

Hidayah, R. U., \& Nazaruddin, I. (2017). The Effect of Leadership Style, Work Motivation, Organizational Culture and Job Discipline on Employees Performance. In ICoSI 2014 (hal. 255-262). Singapore: Springer. https://doi.org/10.1007/978-981-287-661-4_26 
Hilman, H., \& Warokka, A. (2011). The effects of entrepreneurship, competitiveness, and technology innovation on growth: A case of ASEAN economic development. Jurnal Ekonom, 14(3), 1-14.

House, R. J. (1971). A path goal theory of leader effectiveness. Administrative science quarterly, 16, 321-339.

Jacobsen, C. B., \& Andersen, L. B. (2015). Is Leadership in the Eye of the Beholder? A Study of Intended and Perceived Leadership Practices and Organizational Performance. Public Administration Review, 75(6), 829-841. https://doi.org/10.1111/puar.12380

Jansen, M., van Tulder, R., \& Afrianto, R. (2018). Exploring the conditions for inclusive port development: the case of Indonesia. Maritime Policy \& Management, 45(7), 924-943. https://doi.org/10.1080/03088839.2018.1472824

Khan, M. (2012). The impact of training and motivation on performance of employees. Business review, 7(2), 84-95.

Lee, C.-W., \& Hidayat, N. (2018). The influence of transformational leadership and intrinsic motivation to employee performance. Advances in Management and Applied Economics, 8(2), 1-12.

Liu, W., Lepak, D. P., Takeuchi, R., \& Sims Jr, H. P. (2003). Matching leadership styles with employment modes: Strategic human resource management perspective. Human resource management review, 13(1), 127-152. https://doi.org/10.1016/S10534822(02)00102-X

Lumbasi, G. W., K'Aol, G. O., \& Ouma, C. A. (2016). The Effect of Participative Leadership Style On The Performance of COYA Senior Managers in Kenya. Journal of Management, 4(5), 1-12.

Luthans, F. (2006). Perilaku Organisasi. Yokyakarta: Andi.

Mangkunegara, A. P., \& Octorend, T. R. (2015). Effect of Work Discipline , Work Motivation and Job Satisfaction on Employee Organizational Commitment in the Company ( Case Study in PT . Dada Indonesia ). Universal Journal of Management, 3(8), 318-328. https://doi.org/10.13189/ujm.2015.030803

Manuel, C., Marta, F., \& Amparo, C. (2004). Benchmarking the port services: a customer oriented proposal. Benchmarking: An International Journal, 11(3), 320-330. https://doi.org/10.1108/14635770410538781

Martapina, A., \& Warokka, A. (2018). Decentralization and Public Expenditure: Does Special Local Autonomy Affect Regional Economic Growth. Asian International Journal of Social Sciences, 17(2), 123-138.

Maslow, A. (1954). Motivation and Personality. New York: Harper \& Row.

Midgley, C., Kaplan, A., \& Middleton, M. (2001). Performance-approach goals: Good for what, for whom, under what circumstances, and at what cost? Journal of educational psychology, 93(1), 77. https://doi.org/10.1037/0022-0663.93.1.77

Mohamud, S. A., Ibrahim, A. A., \& Hussein, J. M. (2017). The Effect Of Motivation On Employee Performance: Case Study In Hormuud Company In Mogadishu Somalia. International Journal of Development Research, 7(11), 17009-17016.

Morrison, E. W. (1993). Newcomer information seeking: Exploring types, modes, sources, and outcomes. Academy of management Journal, 36(3), 557-589. https://doi.org/10.5465/256592

Muchzen, M., Tamsah, H., \& Ilyas, G. B. (2019). Pengaruh Kompensasi terhadap Kinerja Melalui Motivasi dan Disiplin Kerja Pegawai Kantor Unit Penyelenggara Pelabuhan Garongkong Kabupaten Barru. YUME: Journal of Management, 2(1), 1-17.

Munim, Z. H., \& Schramm, H.-J. (2018). The impacts of port infrastructure and logistics performance on economic growth: the mediating role of seaborne trade. Journal of Shipping and Trade, 3(1), 1. https://doi.org/10.1186/s41072-018-0027-0 
Pradana, S., Bagia, I. W., \& Susila, G. P. A. J. (2016). Pengaruh Kompetensi Interpersonal dan Motivasi Kerja terhadap Kinerja Pegawai. e-Journal Bisma Universitas Pendidikan Ganesha, 4(1), 1-9.

Ratnawati, E., Sukidjo, S., \& Efendi, R. (2020). The Effect of Work Motivation and Work Experience on Employee Performance. International Journal of Multicultural and Multireligious Understanding, 7(8), 109-116.

Risambessy, A., Swasto, B., Thoyib, A., \& Astuti, E. S. (2012). The influence of transformational leadership style, motivation, burnout towards job satisfaction and employee performance. Journal of Basic and Applied Scientific Research, 2(9), 88338842.

Rizan, M., Warokka, A., Wibowo, A., \& Febrilia, I. (2020). Leadership Styles and Customer Loyalty: A Lesson from Emerging Southeast Asia's Airlines Industry. The Journal of Asian Finance, Economics, and Business, 7(9), 477-488.

Salahuddin, M. M. (2010). Generational Differences Impact On Leadership Style And Organizational Success. Journal of Diversity Management (JDM), 5(2). https://doi.org/10.19030/jdm.v5i2.805

Sandhu, M. A., Iqbal, J., Ali, W., \& Tufail, M. S. (2017). Effect of employee motivation on employee performance. Journal of Business and Social Review in Emerging Economies, 3(1), 85-100. https://doi.org/10.26710/jbsee.v3i1.182

Shafie, B., Baghersalimi, S., \& Barghi, V. (2013). The Relationship between Leadership Style and Employee Performance : Case Study of Real Estate Registration Organization of Tehran Province. Singaporean Journal of Business , Economics and Management Studies, 2(5), 21-29. https://doi.org/10.12816/0003885

Shahzadi, I., Javed, A., Pirzada, S. S., Nasreen, S., \& Khanam, F. (2014). Impact of employee motivation on employee performance. European Journal of Business and Management, $6(23), 159-166$.

Sjarief, H. (2020). The Influence, Ability, Motivation Of Perform Of Employees Office In Order To Perak Port Surabaya. Development Economic Journal Research, 5(1), 9-15.

Subari, S., \& Riady, H. (2015). Influence of training, competence and motivation on employee performance, moderated by internal communications. American Journal of Business and Management, 4(3), 133-145.

Sugito, S., \& Ghoniyah, N. (2017). Model of Human Resources Performance Improvement at Port Operator Unit (UPP) Class III Jepara, Pati and Rembang through Knowledge Sharing, Quality of Information Technology and Commitment As Intervening Variable. IJIBE (International Journal of Islamic Business Ethics), 2(3), 125-136.

Sugiyono. (2014). Metode Penelitian Kuantitatif, Kualitatif dan R\&D. Bandung: Alfabeta.

Syafii, L. I., Thoyib, A., Nimran, U., \& Djumahir. (2015). The Role of Corporate Culture and Employee Motivation as a Mediating Variable of Leadership Style Related with the Employee Performance (Studies in Perum Perhutani). Procedia - Social and Behavioral Sciences, 211, 1142-1147. https://doi.org/10.1016/j.sbspro.2015.11.152

Székely, F., \& Knirsch, M. (2005). Responsible leadership and corporate social responsibility:: Metrics for sustainable performance. European Management Journal, 23(6), 628-647. https://doi.org/10.1016/j.emj.2005.10.009

Tammubua, M. H., Febrilia, I., \& Warokka, A. (2015). Testing the competing entrepreneurial intention's antecedents on public university students. Journal of Entrepreneurship: Research \& Practice, Vol. 2015 (2015), Article ID 251294, DOI: 10.5171/2015.251294

Twalib, M. H., \& Kariuki, M. M. (2020). Influence Of Motivation On Employee Performance At Telkom Kenya Limited. International Journal of Business Social Sciences \& Education, 2(11), 421-431. 
Warokka, A. (2010). Estructura de propiedad y gobierno corporativo en las empresas asiáticas tras la crisis financiera de 1997. Revista de Responsibilidad Social de la Empresa 2(2), 141-179.

Warokka, A., Gallato, C. G., Thamendren, A., \& Moorthy, L. (2012). Organizational justice in performance appraisal system and work performance: evidence from an emerging market. Journal of Human Resources Management Research, 2012, 1.

Widodo, D. S. (2014). Influence of Leadership And Work Environment To Job Satisfaction And Impact To Employee Performance (Study On Industrial Manufacture In West Java). Journal of Economics and Sustainable Developmen, 5(26), 62-66.

Yahya, K. K., Mansor, F., \& Warokka, A. (2012). An empirical study on the influence of perceived organizational support on academic expatriates' organizational commitment. The Journal of Organizational Management Studies, Vol. 2012 (2012), Article ID 565439, 1-14. DOI: $10.5171 / 2012.565439$

Wright, B. E. (2007). Public service and motivation: Does mission matter? Public administration review, 67(1), 54-64. https://doi.org/10.1111/j.1540-6210.2006.00696.x

Wulandari, U.N., Ansari, K., and Hadi, W. (2020). The Effect of Cooperative Learning Models and Learning Motivation towards the Skills of Reading Students in Public Elementary School 101883 Tanjung Morawa Sub-district. Budapest International Research and Critics in Linguistics and Education (BirLE) Journal Vol 3 (2): 12091219. 